\title{
Implications of human activities for (re)emerging infectious diseases, including COVID-19
}

\author{
Nundu Sabiti Sabin 1,2,3, Akintije Simba Calliope 1,2,3, Shirley Victoria Simpson 1,2,3, Hiroaki Arima ${ }^{1,2}$, Hiromu Ito ${ }^{1}$, \\ Takayuki Nishimura ${ }^{4,5}$ and Taro Yamamoto ${ }^{1,2,3^{*}}$
}

\begin{abstract}
Since 1980, the world has been threatened by different waves of emerging disease epidemics. In the twenty-first century, these diseases have become an increasing global concern because of their health and economic impacts in both developed and resource-constrained countries. It is difficult to stop the occurrence of new pathogens in the future due to the interconnection among humans, animals, and the environment. However, it is possible to face a new disease or to reduce the risk of its spread by implementing better early warning systems and effective disease control and prevention, e.g., effective global surveillance, development of technology for better diagnostics, effective treatments, and vaccines, the global political will to respond to any threats and multidisciplinary collaboration involving all sectors in charge of good health maintenance. In this review, we generally describe some factors related to human activities and show how they can play a role in the transmission and spread of infectious diseases by using some diseases as examples. Additionally, we describe and discuss major factors that are facilitating the spread of the new pandemic known as COVID-19 worldwide.
\end{abstract}

Key words: Humans, Factors, (Re)emerging infectious disease, Coronavirus

\section{Background}

Emerging infectious diseases (EIDs) are diseases recently identified or previously unknown infections that cause public health threats, either locally or internationally [1]. In contrast, reemerging infectious diseases are known diseases that reappear and increase in incidence but that in the past may have fallen to levels so low that they were no longer considered a public health problem [1]. In the twenty-first century, these diseases have increasingly become a global concern [2] due to their health and economic impacts in both developed and resource-

\footnotetext{
* Correspondence: taro.daichi.yamamoto@gmail.com

${ }^{1}$ Department of International Health and Medical Anthropology, Institute of Tropical Medicine, Nagasaki University, 1-12-4 Sakamoto, Nagasaki 852-8523, Japan

${ }^{2}$ Graduate School of Biomedical Sciences, Nagasaki University, Nagasaki, Japan

Full list of author information is available at the end of the article
}

constrained countries. It has been estimated that out of approximately 400 known emerging pathogens, 25\% occur as human pathogens [3]. In other reports, approximately 175 species are associated with emerging diseases, of which approximately $75 \%$ are of zoonotic origin [4]. Most of these zoonoses have occurred due to increased contact between humans and animals [5-8]. These zoonoses account for approximately $44 \%, 30 \%$, $11 \%, 9 \%$, and $6 \%$ of viruses or prions, bacteria or rickettsia, protozoa, fungi, and helminths, respectively [9]. In the post-1980 period, some zoonotic pathogens were responsible for outbreaks such as Escherichia coli $\mathrm{O} 157$ in the 1980s [10], the avian strain of influenza in HongKong in 1997 [11], West Nile virus in 1999 [12], the outbreak of chikungunya fever in Italy in 2007 [13], the epidemic of Q fever in the Netherlands $[14,15]$, the outbreak of severe acute respiratory syndrome (SARS) in 
2002 caused by very virulent strains of new coronaviruses [16-18], Middle East respiratory syndrome coronavirus (MERS-CoV) in 2012 [19], and avian influenza, such as A/H1N1 in 1997 in Hong-Kong [20], A/ H7N7 in 2004 in the US [21], A/H7N2 in 2007 in the UK [22], and A/H7N9 in China [20, 23]. Recently, major outbreaks of Ebola virus disease (EVD) threatened populations in West African countries between 2013 and 2016, with 28,603 cases and 11,310 deaths [24], and in the Democratic Republic of Congo (DRC) from 2018 to 2020, with 3444 cases and 2264 deaths [25]. Currently, the entire world is facing an unprecedented pandemic caused by a new strain of coronavirus called coronavirus disease 2019 (COVID-19) [26].

Wolfe et al. [27] identified five stages leading to endemic human disease, where a pathogen restricted to infecting animals may be transformed into a human pathogen. The first stage is when a pathogen is present in animals but has not yet been detected in humans under natural conditions; the second is when a pathogen has been transmitted from animals to humans, but there is no evidence of human-human transmission (e.g., tetanus, rabies); the third is when a pathogen can undergo only a few cycles of secondary transmission between humans and shortly die out, where a subsequent wave will require the involvement of animal hosts (e.g., Ebola virus, Marburg virus, monkeypox virus); the fourth is when a pathogen undergoes long sequences of secondary transmission between humans without the involvement of animal hosts (many vector-borne diseases, e.g., dengue virus, yellow fever virus, cholera, influenza A, typhus); and the fifth is when a pathogen previously restricted to animals later evolves into an exclusively human pathogen (e.g., smallpox, measles, syphilis, falciparum malaria, rubella, mumps, hepatitis B, tuberculosis, AIDS) [27]. Consequently, the passage from one stage to another depends on the host-pathogenenvironment interconnection [28]. The emergence of infection is influenced by the interconnecting domains of determinants such as physical and environmental factors; ecological factors; genetic and biological factors; and social, political, and economic factors [29]. Therefore, these determinants may influence the emergence and spread of infectious diseases. According to Chareonsook et al. [30], human demographic changes and behavior, travel and commerce, ecological changes, technology and industry, microbial adaptation and change, and the breakdown of public health measures are sufficient factors for the emergence and spread of infectious diseases. Subsequently, Lederberg et al. [29] identified additional factors such as human vulnerability, economic development, land use, lack of political will, poverty and social inequality, war and famine, and intent to harm.
In the twenty-first century, many outbreaks have occurred around the world, such as EVD, avian influenza, and coronaviruses (SARS, MERS, COVID-19), because of factors related to human activities. Here, we will describe some human-related factors and give some examples.

\section{Human-related factors influencing the transmission and spread of infectious diseases} Globalization (international travel and trade)

The twenty-first century has ushered in an era where infectious diseases are occurring at an unprecedented frequency and speed. A coordinated global response is needed; however, in this globalized environment of interdependent trade, travel, and migrations, pathogens have no geopolitical borders [2,31].

Recently, EIDs such as COVID-19, EVD, Lassa fever, and SARS have been an issue of global concern. With globalization, the risk of the emergence of new diseases is increasing since humans have more chances to be exposed to new pathogens. Additionally, the risk of international spread of infectious diseases is increasing because of increased international travel. The process of globalization potentially influences a broad range of biological, environmental, and social factors that affect the burden of many critical human infections [32]. Various international organizations and governments have been trying to establish better global systems to respond to EIDs. However, the SARS outbreak in 2003, the EVD outbreak in West Africa in 2014, and the current COVID-19 pandemic have highlighted that the current global system is still not fully ready for such (re)emerging infectious diseases [33]. These EIDs threaten public health, as well as the global economy, and are sustained by increasing global trade and travel. However, the disruption of the human-ecological system is another potential factor. Travelers could play a role in importing EIDs and could be a carrier of major epidemics [34]. It has been observed that (re)emerging infectious diseases are imported by travelers or tourists in Europe, such as chikungunya and dengue in France and Italy as well as COVID-19 in France from China [35-37]. Cross-border movements of people, as well as trade in goods and services, are increasing the challenges for infectious disease control. As an example, in 2005, evidence of outbreak importation through international travel was found with the isolation of H5N1 type A influenza virus from two mountain hawk eagles that were illegally imported from Thailand in an airline cabin carry-on baggage to Belgium [38]. The risk of infectious diseases rises with the increased mobility of people, growth in the international trade in food and biological products, and social and environmental changes. It is evident that trade and international travel are essential to humankind. However, 
some preventive measures, such as travel restrictions and creation of awareness among trade and travel stakeholders, are paramount to flatten the curve. In recent years, trade embargoes or travel restrictions have been replaced with sensitive early warning surveillance, rapid verification procedures, and international response networks as well as epidemic preparedness through stockpiles of essential medicines [39, 40]. However, studies have proven that if implemented within 2 weeks of cases, travel restrictions are $99 \%$ effective in conjunction with border restrictions that prevent the entry of infected travelers. Additionally, a $90 \%$ restriction on longdistance flights can lead to delays in the epidemic peak that range from a few days to a few weeks [41-44]. These developments affect all elements of the infectious disease chain: hosts, agents, and vectors [45]. Moreover, we must not ignore the fact that outbreaks are themselves associated with significant costs in terms of lost trade and tourism revenue. Therefore, a fear of economic penalties and social stigma can arise and can sometimes lead authorities to underreport data in epidemics, hence risking serious public health consequences.

\section{Changes in environment/ecological changes}

Global environmental changes are due to human modifications to the environment [46]. National, regional, and global environmental threats to human health according to the World Health Organization (WHO) include "climate change, stratospheric ozone depletion, changes in ecosystems due to loss of biodiversity, changes in hydrological systems and the supplies of fresh water, land degradation, urbanization, and stresses on foodproducing systems" [47].

Changes in the environment, including food-handling practices, agriculture, and changes in water ecosystems, seem to increase the chance of contact with a reservoir host encountering microorganisms previously unknown to humans. Anthropogenic changes alter the environment by increasing the risk of transmission of pathogens unfamiliar to humans [48].

It has been established that there is a relationship between infectious disease outbreaks and changes in the environment, including climate change events [49]. Ecological changes are one of the most important drivers of (re)emerging infectious diseases, specifically agricultural development, climate changes, food-handling practices, changes in water ecosystems, deforestation, and reforestation [48, 50, 51].

Climate change results in differences in weather conditions and patterns of extreme weather events. Spatiotemporal changes in climate affect the reproduction, development, survival, and livability of pathogens, hosts, and their interaction with human beings. Dramatic and unforeseen changes in weather conditions have profound effects on many infectious diseases. Extreme weather events and meteorological hazards make it more complicated to predict the implications for disease pathogens, hosts, and transmission [52-54]. The United Nations High Commissioner of Refugees (UNHCR) estimates that an average of 22.5 million people have been displaced by weather-related events or climate since 2008 [55]. The literature on climate variations and infectious diseases demonstrates that climate-sensitive diseases, i.e., vector-borne and food/water-borne diseases, are vastly affected by climate variability and climate change [56, 57]. Vector-borne diseases (VBDs) are the most climate sensitive. They have several climate drivers [58], causing over 700,000 deaths annually, accounting for more than $17 \%$ of all infectious diseases and having the highest burden in tropical and subtropical areas, particularly affecting the most deprived populations [59]. Some examples of VBDs of significance to humans and animals are malaria, schistosomiasis, dengue, chikungunya, and Lyme disease [60-62]. Improving infrastructure and disease surveillance systems worldwide and funding health observatories would help to better detect and attribute the effects of climate change on VBD (re)emergence [60-62]. The burden of food- and water-borne diseases (FWBDs) is found in some parts of developing countries and areas where food and water hygiene are inadequate. For example, in Africa, FWBDs account for 91 million illnesses, resulting in 137,000 deaths, annually [63]. Important causes of food-borne diseases are noroviruses, Campylobacter spp., and nontyphoidal Salmonella, while those of water-borne diseases remain diarrheal diseases, such as cholera, Shigella, and poliomyelitis. Additionally, food-handling practices have been associated with SARS and H5N1 outbreaks [48]. Proper water, sanitation, and hygiene interventions can significantly reduce FWBDs [63].

Agricultural development is a factor and the most typical way humans alter and interpose themselves into the environment $[64,65]$. It is the world's single most significant driver of global environmental change and is key to attaining Sustainable Development Goal (SDG) 2 , which aims to end hunger, achieve food security and improved nutrition, and promote sustainable agriculture $[66,67]$. The expansion and intensification of agriculture come with massive habitat conversion, increasing use of agricultural inputs such as antibiotic growth promoters and pesticides, and contamination with animal waste [68]. Several studies have linked agricultural land use or land use change with infectious disease risks. Significant associations were identified for malaria, spotted fever group rickettsioses, hookworm, scrub typhus, Schistosoma japonicum, and Trichuris trichiura. 
On the other hand, agricultural practices were implicated in the pandemic influenza outbreak, Nipah, and West Nile transmission [48]. Exposure to livestock could result in 2-4 times the risk of infection with vector-borne, bacterial, or zoonotic diseases [69]. To withstand the future viability of agriculture, sustainable practices are required to meet rising human needs while contributing to the resilience and sustainability of landscapes, biospheres, and the Earth system [67]. It has also been shown that deforestation and reforestation can influence the emergence of some pathogens. For example, reforestation has been linked to Lyme disease outbreaks [56, 70].

\section{Human-wild animal interface}

Approximately three-fourths of human EIDs are caused by zoonotic pathogens [71]. However, according to the WHO, humans coexist with animals in a variety of ways, either by hunting [72] or by living as domestic animals [73]. The interface among humans, animals, and the environment we share can be a source of diseases impacting public health [74]. However, in most cases, reported causes for and drivers of the apparent trends in disease emergence are lacking in intense evidence-based research. However, there is circumstantial evidence to suggest that novel epidemics and disease syndromes are the results of changing agroecology and human behavior and movements, intensifying interfaces with certain wildlife species and climate change $[6,75]$. Although no clear evidence has been presented to date, hunting has been associated with zoonotic diseases [72]. With modern ways of life, however, this hypothesis became obsolete with the low spillover from wild animals to humans. The possible reason was that when people lived as hunter-gatherers, they were always on the move, and it became difficult for microbes to keep up with their human hosts. Once people started living as farmers, they began residing in more significant numbers in the same place and were in daily contact with their accumulating feces for extended periods [76]. Other evidence has shown that bushmeat is an essential source of protein and income in Africa despite its link with numerous EIDs, such as Ebola and Marburg [7]. The increased demand and commercialization of these types of meat have exposed people to pathogens and thus facilitated the geographic spread of the diseases [77]. All the aspects highlighted above have created conditions highly amenable for the spillover of microbes into the human ecosystem.

Moreover, the domestication of wild animals has narrowed the gap between wild animals and humans. Evidence has shown that domesticated animals that were long ago associated with humans are the ones at the center of those that favor parasite/pathogen transmission not only to humans but also to all other domesticated animals [78]. It has been revealed not only that humans are victims of the domestication of wild animals but also that the reverse is true. An example is that the occurrence of Taenia tapeworms in humans predated the development of agriculture, animal husbandry, and domestication of cattle or swine, and later, it accompanied early human dispersion out of Africa. Swine and cattle are thought to have acquired infections with Taenia species during their early domestication [79]. Thus far, it is not possible to stop human-animal interconnections. However, it is possible to reduce the negative impact of the human-wild animal interface, which contributes to the emergence of infectious diseases, by responding before the occurrence of spillover events, epidemics or even pandemics [80]. For example, people should be educated to stop harvesting bushmeat, especially by avoiding nonhuman primates; future zoonotic spillover events should be prevented through culturally appropriate education, and disease spread should be avoided through better disease surveillance $[81,82]$.

\section{Antimicrobial resistance}

The resistance of microbes (viruses, bacteria, parasites, and fungi) to antimicrobials has contributed to the reemergence of many diseases that were no longer considered a public health problem [83], narrowing the range of antimicrobial drugs and representing a global public health concern [84-86]. It has been estimated that approximately 700,000 annual deaths worldwide are a result of antimicrobial resistance (AMR) [87], which poses a problem to achieve the United Nations SDGs [88] and might reduce the gross domestic product by approximately $3.8 \%$ by 2050 [89].

It has been shown that AMR is the consequence of microbial adaptation and genetic changes that allow them to bypass the human immune system, infect human cells, and spread disease. These microbes can emerge and spread rapidly and become resistant to multiple antimicrobials at the same time [90-94] by developing mechanisms to exchange or incorporate new genetic material into their genomes, exchanging virtually any stretch of DNA or RNA [95]. Sometimes, even doctors prescribe inappropriate antimicrobials (i.e., an antimicrobial is not needed at all, or they prescribe the wrong drug or wrong dose) [96], or physicians prescribe drugs with the wrong prescription doses or antibiotics with an incorrect duration of treatment [97]. This practice contributes to the growth and spread of microbial resistance [98] and can be responsible for nosocomial infections in hospitals. For instance, more than $90 \%$ of Staphylococcus aureus species were resistant to penicillin and beta-lactam antibiotics in hospitals in the United States (US) and were responsible for approximately 19, 
000 deaths in 1992 [83]. Additionally, between 1989 and 1993, the incidence of vancomycin-resistant enterococci increased 20-fold in the US, and in 1997, the susceptibility of Staphylococcus aureus to vancomycin decreased in both the US and Japan [99]. In the European Union (EU), approximately $15-50 \%$ of Klebsiella pneumoniae species are resistant to carbapenems [100]. Previously, methicillin-resistant Staphylococcus aureus (MRSA) was associated with severe invasive disease only in hospitals; however, in the last 20 years, it has been identified in the community and named community-associated (CA)MRSA [101]. As an example, CA-MRSA pneumonia is responsible for approximately $75-85 \%$ of admitted patients and 20 to $60 \%$ of deaths in the intensive care unit [102]. Currently, extended-spectrum $\beta$-lactamase resistance is endemic in hospitals and the community worldwide $[103,104]$.

Moreover, multidrug-resistant (MDR)-Acinetobacter baumannii isolates carrying Cefotaxime-M (CTX-M) enzymes are now responsible for nosocomial infections and among specific populations and accountable for high mortality and morbidity [105], as well as cholera O1 and O139 [106-109]. Additionally, it has been shown that the prevalence of MDR-TB among new TB cases increased from $12 \%$ in 2009 to $13.7 \%$ in 2010 in the EU. Thus, drug-resistant TB is still a major concern despite a decrease in TB incidence in subsequent years $[110,111]$.

The use of antimicrobials as additives in plant agriculture (fruits, vegetables, orchids, etc.) and animals and, more importantly, food-producing animals can lead to the development of resistant bacteria [112]. Thus, resistant genes in animals can be transferred to humans through the consumption of food or direct contact with food-producing animals or through environmental spread [113-122]. The misuse of antimicrobials, especially in developing countries, is mainly due to their unregulated supply chain, the availability of over-thecounter drugs [123-126], and self-medication [125, 127-131], which is amplified by poverty [131]. Up to half of all antibiotics prescribed are misused and neither needed nor effective [132, 133]. Another situation is the discontinuation of treatment by patients with a recurrent infection, which contributes to the development of a virulent and resistant strain of the microbe [130]. All these factors contribute to genetic selection pressure for the emergence of MDR bacterial infections in the community. Given the factors that contribute to the rise of AMR, reducing its risk implies the need to improve in ensuring the appropriate use of antibiotics through the enforcement and improvement of legislation on prescribing and dispensing antibiotics. In addition, the use of antibiotics in animal medicine and food production must be regulated. The government, pharmacists, doctors, veterinarians, and agronomists must work together and establish national guidelines for dispensing and prescribing antimicrobials. Adequate training on the proper prescription of antimicrobials must be given to health professionals, and the population must be educated on the use of antimicrobials and the threat of AMR.

\section{Host susceptibility}

Human susceptibility may influence the emergence of infectious diseases through genetic polymorphisms, impaired immune function, malnutrition, AIDS, immunosuppressive conditions, aging, and others. Innate and acquired immune defenses help humans to fight against infectious diseases. Genetic polymorphisms are potent natural selective forces for pathogens to induce human defenses against infection [134-136]. People suffering from hemoglobinopathy $\mathrm{S}$ homozygosity develop more severe Plasmodium falciparum infection than those who have hemoglobin S heterozygotes [136, 137]. Malnutrition also increases the severity of some infectious diseases. Thus, malnourished children have a higher risk of death from diarrhea, acute respiratory infections, and possibly malaria [138]. According to the WHO, 26\% of the world's malnourished children have been affected by population displacements, natural disasters, wars, civil disturbances, and population growth in the region [139]. Considering immunosuppressive conditions, people who suffer from HIV/AIDS and cancers have a higher risk of increased disease severity. For example, the emergence of fungi, such as Aspergillus spp., and other opportunistic agents that were previously uncommon or unrecognized have increased in populations with cancer chemotherapy, organ, and tissue transplantation, or those infected with HIV [140]. It has also been shown that more than $10 \%$ of cancers or transplants are either colonized or infected with vancomycin-resistant enterococci [141].

\section{Behavior changes}

Human behavior has been an essential factor in the transmission of emerging infectious pathogens. Understanding community behavior during epidemics is key to improving control strategies [142]. Behavior changes are often linked to culture, which refers to integrated patterns of human behavior that include the beliefs, language, communications, actions, and organizations of racial, ethnic, religious, or social groups [143]. Many infectious disease outbreaks sensibly spread because of these factors. Since the occurrence of HIV/AIDS and Ebola, for example, stigmatization, discrimination, ignorance, trust, and misinformation have been the root of the spread of these diseases [144-146]. 
Another situation concerns human behavior changes related to conflicts. Conflicts of human behavior occur where people are interconnected, and they result from a variety of attitudes, needs, beliefs, and ways that humans react to different situations [147]. Conflict situations can potentiate the (re)emergence and transmission of infectious diseases and are characterized by war or civil strife. This usually leads to the displacement of large populations, interruption of primary care and immunization programs, inadequate safe water supply, poor sanitation, and increased exposure to disease vectors [67-69]. According to UNHCR, 70.8 million people around the world are forcibly displaced, constituting 41.3 million internally displaced people, 25.9 million refugees, and 3.5 million asylum-seekers [70] from Africa to the Middle East, South Asia, and Europe [148, 149]. Millions of people live in deplorable conditions, and healthcare facilities in host countries are overburdened; these conditions are suitable for the (re)emergence of infectious diseases [70, 150]. Displaced populations are prone to viral and bacterial respiratory infections, nosocomial antibiotic-resistant bacterial infections, cholera, cutaneous leishmaniasis, sexually transmitted infections, poliomyelitis, Chagas, schistosomiasis, hepatitis B and C, meningococcal infections, and VBDs [57, 151-154]. It would be better to (1) strengthen health systems in all countries; (2) evaluate the detection, containment, treatment and control of infectious diseases, including the implementation of surveillance systems; and (3) devise strategies for epidemics and protect health-supporting infrastructure and health workers during conflict situations and the aftermath, ultimately striving to achieve health equity by key policy actors $[68,81,151,155,156]$.

\section{Factors related to the spread of COVID-19}

COVID-19 is caused by a virus officially named severe acute respiratory syndrome coronavirus-2 (SARS-Cov-2) $[157,158]$. It is a new pandemic that started in December 2019 in Wuhan, Hubei Province of China [159-161]. The disease rapidly spread from Wuhan to the rest of Mainland China and other parts of the world, affecting at least 216 countries and territories, with 15,745,102 confirmed cases and 639,317 confirmed deaths as of 26 July $2020[26,162,163]$. Countries are reacting differently regarding the WHO-recommended preventive measures (lockdown, test-trace isolation, wearing masks and wearing them correctly, covering the mouth when coughing and sneezing, keeping at least one meter of social distance, frequent washing of hands and avoiding direct contact of the eyes, nose, and mouth [164]), making some countries more affected than others. Therefore, the variation in the severity, frequency, and amplitude of this pandemic is due to the addition of several factors as well as government policies.
Human behavior is an essential determinant of the transmission and spread of COVID-19 because the pandemic is spread by individual movements through large droplets and contacts, and possibly by aerosols and fomites, from person to person with direct or indirect contact based on the experience with SARS-CoV and MERS-CoV [165-167]. Self-protection may be the critical determinant for the prevention of COVID-19 [168] from one person to another because when a person protects himself or herself, he or she also protects others. Thus, understanding the collective behavior between and within individual groups would be useful for decision-making. Behavioral differences regarding COVID-19 containment measures such as lockdowns, social distancing, and the use of facial masks may cause some individuals to be more at risk than others and some countries to be more affected than others. Community behavior regarding preventive measures is influenced by cultural habits and misinformation. For example, there was also a great deal of misinformation and rumors that were widespread among the Chinese population and abroad with regard to the virus origin [169-172], transmission mode, treatment, prevention, and control measures $[173,174]$. In addition, the WHO also created misinformation at the beginning of the pandemic by restricting the wearing of masks only to sick people showing symptoms and those who are caring for people with suspected infection [175]. Thus, some countries advised populations to wear masks only in enclosed spaces such as shops or public transport. Additionally, misinformation created from social media and websites with no credible evidence has generated changes in the behavior of many people, increasing the frequency and spread of COVID-19 locally, regionally, and internationally [176, 177]. In some countries, such as Japan, Singapore, China, and South Korea, cultural habitssuch as the culture of mask-wearing, minimal personal contact, improved hand sanitization, and fanciful suggestions that Japanese speakers emit fewer potentially virusladen droplets when talking than do speakers of other languages-have helped to flatten the curve and to limit the spread of COVID-19 in communities [178, 179]. On the other hand, in Western countries such as Italy, Spain, the United States, the United Kingdom, France, and many other countries where the culture of maskwearing is not a habit and where hugging, kissing, shaking hands, spending time together, and engaging in other social practices are common, the virus has spread quickly [180, 181].

Another factor is the lack of transparency from government, and politicization of this outbreak by politicians has created confusion among communities and urged people not to follow prevention and control measures such as early detection, isolation, and treatment of 
cases, contact tracing, and containment measures in communities to prevent disease transmission within and between societies.

Host susceptibility includes aged individuals and other individuals with compromised immunity (such as high blood pressure, HIV, kidney diseases, diabetes, and cancers) who face higher risks of COVID-19 [182-184]. Immune-compromised individuals are in a highly susceptible group, as their host defense is indigent; their defenses are already down, which could result in an increasingly poor prognosis for them [182]. Atmospheric temperature variation also plays a role in the spread of COVID-19. It is known that winter is the flu season in cold temperate countries because influenza viruses survive better in cold-dry weather with reduced ultraviolet light. Reduced innate immunity is due to low levels of vitamin $\mathrm{D}$ and melatonin and to staying indoors frequently during winter, increasing opportunities for the virus to spread among people [185, 186]. COVID-19 started during winter, and it has been shown that the local immune response in the nasal passage is reduced in people during cold winter, making them more susceptible to flu-like viruses [186]. This situation may make people living in such areas more vulnerable than those living in tropical areas, leading to differences in the spatial distribution of COVID-19 worldwide.

High temperature may be a protective factor, as it can provoke the evaporation of respiratory droplets, reducing infectivity [187-189]. African and Asian tropical countries where high temperatures and high relative humidity are common may be protected from COVID-19 because of their negative effect on the spread of the disease. On the other hand, in Western countries where there are low temperatures and high humidity, its transmission in air-conditioned and temperate climatic environments may be facilitated $[187,189]$. Closed areas with low airflow and ventilation have been shown to play a role in the increasing risk of COVID-19 infection [162], which makes developed countries at greater risk than developing countries. For instance, in developing countries, apart from some places in large cities, most people live under more natural atmospheric temperatures than do people in Western countries, where most houses are built with air-conditioning systems. Living in airconditioned housing in addition to other factors, such as being older, having respiratory diseases or diabetes, or being an immune-compromised person, may increase the risk of transmission of COVID-19 [190-193].

High population density has also been associated with the spread of epidemics, including COVID-19 [194]. In the case of COVID-19, a high number of cases have been observed in overcrowded cities in countries such as China, Japan, India, and the United States. Additionally, countries with a high proportion of elderly populations, such as Italy and Spain, have a higher risk of severity [181], and this risk increases when young and older people live together [195].

International travel and trade have facilitated the spread of COVID-19. In the past, humanity has survived previous pandemics by infectious agents such as influenza viruses. However, the present one is unprecedented in its capacity to take advantage of modern globalization, allowing for the massive transborder spread at a surprising speed [196]. With the current international travel and trade, it has been quite difficult to contain the spread of this virus. Countries have tried to impose travel restrictions and have reduced the exportation rate from mainland China, but these restrictions are insufficient to contain the geographic spread. Such measures have led to discrimination against foreigners [197]. However, travel restrictions cannot be expected to fully apprehend the global expansion of COVID-19 but may decrease the rate of case exports if enacted during the early stages of the epidemic. This is because the onset of symptoms at the time of arrival is, in most cases, not detectable as the virus is still under incubation period [198].

Delayed government response, inadequate infrastructures, and lack of biosafety and biosecurity awareness have also contributed to the transmission and spread of COVID-19. Most countries have facilitated the transmission and spread of the disease due to inadequate preventive and/or mitigating strategies. Many countries failed to prevent the epidemic in the beginning by delaying preventive measures. However, a few countries succeeded in controlling the outbreak by adopting an effective mitigating strategy. South Korea and other countries, such as Singapore, Hong Kong, Japan, and Germany, quickly responded after the first case by adopting a strategy involving the testing and isolation of cases, contact tracing, and quarantining of suspected cases to suppress the full transmission of the virus in communities [199]. Additionally, countries that have experienced SARS-like epidemics such as Taiwan, Hong Kong, and South Korea have successfully prevented the spread of COVID-19 from China by adopting preventive measures such as travel bans, closing of borders to nonresidents, and 14-day quarantines [200]. Regarding lockdown measures, in the beginning, some countries delayed adopting this strategy because they sought to prevent harm to their economy (including some developed and developing countries) and because of poverty, especially in developing countries, where people are forced to go out as they need to work for their daily livelihood.

Inadequate infrastructures and equipment and lack of awareness regarding laboratory biosafety and biosecurity in certain countries, especially in developing countries, 
have contributed to the spread of the disease in hospitals. Handling pathogens, especially viruses, may expose health workers to a high risk of contamination if they are not well trained. Thus, to prevent nosocomial infections, sufficient training of health workers in the principles and procedures of good laboratory practice (GLP) is needed. Health workers should be well trained on biohazards and the safe management of biological agents in the laboratory. Laboratory workers must have sufficient knowledge and experience about how to handle emerging pathogens safely and securely [201, 202]. However, good awareness of GLPs must be reinforced by the availability of adequate equipment and infrastructures. In many countries, health professionals are working without PPE and are exposed to the infection. Thus, the lack of awareness about COVID-19 preventive measures cause health workers to be exposed and become infected. Additionally, the lack of testing kits, ventilators, and other equipment is impeding some countries from adopting an effective testing and tracing strategy and preventing deaths among severe cases.

\section{Conclusions}

Human activities are still the significant determinants of the transmission and spread of (re)emerging infectious diseases. To date, we are still dealing with the COVID19 pandemic, and it is challenging to predict when it will end. However, it is possible to face the disease or to reduce the risk of its transmission and spread by changing human behavior and implementing better early warning systems and effective disease control and prevention. Thus, effective global surveillance, global political will, and multidisciplinary collaboration of all stakeholders will be helpful in responding to any future threats.

\section{Abbreviations \\ AIDS: Acquired immunodeficiency syndrome; AMR: Antimicrobial resistance; CA-MRSA: Community-associated methicillin-resistant Staphylococcus aureus; CDC: Centers for Disease Control and Prevention; COVID-19: Coronavirus disease 2019; CTX-M: Cefotaxime-M; DRC: The Democratic Republic of the Congo; EIDs: Emerging infectious diseases; EVD: Ebola virus disease; FWBDs: Food- and water-borne diseases; HIV: Human immunodeficiency virus; MARS: Middle East respiratory syndrome; MDR: Multidrug-resistant; MRSA: Methicillin-resistant Staphylococcus aureus; SARS: Severe acute respiratory syndrome; SDGs: Sustainable Development Goals; \\ TB: Tuberculosis; EU: European Union; UK: United Kingdom of Great Britain and Northern Ireland; UNHCR: The Office of the United Nations High Commissioner for Refugees; US: The United States; VBDs: Vector-borne diseases; WHO: World Health Organization}

\section{Acknowledgements}

Not applicable.

\section{Authors' contributions}

NSS and TY participated in the design of the study; NSS, ASC, and SVS searched the literature, selected the reviewed articles, and wrote the draft of the manuscript. HA, HI, and TN also contributed to the design of the study and wrote the manuscript. All authors approved the final version of the manuscript.

\section{Funding}

This work was supported by Grants-in-Aid for Scientific Research (KAKENHI No. JP19K24679) from the Japan Society for the Promotion of Science.

\section{Availability of data and materials}

Not applicable.

\section{Ethics approval and consent to participate}

Not applicable.

\section{Consent for publication}

Not applicable.

\section{Competing interests}

The authors declare that they have no competing interests.

\section{Author details}

${ }^{1}$ Department of International Health and Medical Anthropology, Institute of Tropical Medicine, Nagasaki University, 1-12-4 Sakamoto, Nagasaki 852-8523, Japan. ${ }^{2}$ Graduate School of Biomedical Sciences, Nagasaki University,

Nagasaki, Japan. ${ }^{3}$ Leading Program, Graduate School of Biomedical Sciences, Nagasaki University, Nagasaki, Japan. ${ }^{4}$ Department of Human Science, Faculty of Design, Kyushu University, Fukuoka, Japan. ${ }^{5}$ Department of Public Health, Graduate School of Biomedical Sciences, Nagasaki University, Nagasaki, Japan.

Received: 21 May 2020 Accepted: 16 September 2020

Published online: 25 September 2020

References

1. World Health Organization. Division of emerging other communicable diseases surveillance control emerging infectious diseases. Geneva: World Health Organization; 1997.

2. Mackey TK, Liang BA. Lessons from SARS and H1N1/A: employing a WHOWTO forum to promote optimal economic-public health pandemic response. J Public Health Policy. 2012;33:119-30.

3. Woolhouse ME, Taylor LH, Haydon DT. Population biology of multihost pathogens. Science. 2001;292:1109-12.

4. Slingenbergh Jl, Gilbert M, de Balogh Kl, Wint W. Ecological sources of zoonotic diseases. Rev Sci Tech. 2004;23:467-84.

5. Heymann DL, Dixon M. Infections at the animal/human interface: shifting the paradigm from emergency response to prevention at source. Curr Top Microbiol Immunol. 2013;366:207-15.

6. Jones BA, Grace D, Kock R, Alonso S, Rushton J, Said MY, et al. Zoonosis emergence linked to agricultural intensification and environmental change. Proc Natl Acad Sci U S A. 2013;110:8399-404.

7. Jones KE, Patel NG, Levy MA, Storeygard A, Balk D, Gittleman JL, et al. Global trends in emerging infectious diseases. Nature. 2008:451:990-3.

8. Murphy FA. Emerging zoonoses: the challenge for public health and biodefense. Prev Vet Med. 2008;86:216-23.

9. Taylor LH, Latham SM, Woolhouse ME. Risk factors for human disease emergence. Philos Trans R Soc Lond Ser B Biol Sci. 2001;356:983-9.

10. Barry L. A national food-safety initiative : report to the president may 1997. Washington, DC: National Academies Press; 1998.

11. Marwick C. Investigators present latest findings on Hong Kong 'bird flu' to the FDA. JAMA. 1998;279:643-4.

12. Centers for Disease Control Prevention. Outbreak of West Nile-like viral encephalitis--New York, 1999. MMWR Morb Mortal Wkly Rep. 1999;48:845.

13. Rezza G, Nicoletti $L$, Angelini R, Romi R, Finarelli AC, Panning M, et al. Infection with chikungunya virus in Italy: an outbreak in a temperate region. Lancet. 2007;370:1840-6.

14. van der Hoek W, Dijkstra F, Schimmer B, Schneeberger PM, Vellema P, Wijkmans C, et al. Q fever in the Netherlands: an update on the epidemiology and control measures. Euro Surveill. 2010;15:19520.

15. van der Hoek W, Morroy G, Renders NH, Wever PC, Hermans MH, Leenders AC, et al. Epidemic Q fever in humans in the Netherlands. Adv Exp Med Biol. 2012;984:329-64.

16. Severe acute respiratory syndrome (SARS). Wkly Epidemiol Rec. 2003;78: 81-3.

17. Pugliese A, Beltramo T, Torre D. Emerging and re-emerging viral infections in Europe. Cell Biochem Funct. 2007;25:1-13. 
18. Snell NJ. Novel and re-emerging respiratory infections. Expert Rev AntiInfect Ther. 2004;2:405-12.

19. World Health Organization. Middle East respiratory syndrome coronavirus (MERS-CoV). 2019. https://www.who.int/en/news-room/factsheets/detail/middle-east-respiratory-syndrome-coronavirus-(mers-cov). Accessed 26 Jul 2020.

20. World Health Organization. Influenza (avian and other zoonotic). 2018. https://www.who.int/news-room/fact-sheets/detail/influenza-(avian-andother-zoonotic). Accessed 26 Jul 2020.

21. Fouchier RA, Schneeberger PM, Rozendaal FW, Broekman JM, Kemink SA, Munster $V$, et al. Avian influenza A virus (H7N7) associated with human conjunctivitis and a fatal case of acute respiratory distress syndrome. Proc Natl Acad Sci U S A. 2004;101:1356-61.

22. Avian influenza $A($ H7N2) outbreak in the United Kingdom. Euro Surveill. 2007;12:E070531.2

23. Gao R, Cao B, Hu Y, Feng Z, Wang D, Hu W, et al. Human infection with a novel avian-origin influenza A (H7N9) virus. N Engl J Med. 2013;368:1888-97.

24. World Health Organization. Ebola situation report. 2016. https://apps.who. int/ebola/current-situation/ebola-situation-report-16-march-2016. Accessed 26 Jul 2020

25. World Health Organization. Ebola virus disease? Democratic republic of the Congo. 2020. https://www.who.int/csr/don/12-March-2020-ebola-drc/en/. Accessed 16 Jul 2020.

26. World Health Organization. Coronavirus disease (COVID-2019) situation reports. 2020. https://www.who.int/emergencies/diseases/novelcoronavirus-2019/situation-reports. Accessed 26 Jul 2020.

27. Wolfe ND, Dunavan CP, Diamond J. Origins of major human infectious diseases. Nature. 2007;447:279-83.

28. Snieszko SF. The effects of environmental stress on outbreaks of infectious diseases of fishes. J Fish Biol. 1974;6:197-208.

29. Lederberg J, Hamburg MA, Smolinski MS. Microbial threats to health: emergence, detection, and response. Washington, DC: National Academies Press; 2003.

30. Chareonsook O, Foy HM, Teeraratkul A, Silarug N. Changing epidemiology of dengue hemorrhagic fever in Thailand. Epidemiol Infect. 1999;122:161-6.

31. Frieden TR, Tappero JW, Dowell SF, Hien NT, Guillaume FD, Aceng JR. Safer countries through global health security. Lancet. 2014;383:764-6.

32. World Health Organization. Globalization and infectious diseases: a review of the linkages. 2004. https://www.who.int/tdr/publications/documents/seb_ topic3.pdf. Accessed 26 Jul 2020.

33. Oshitani H. Globalization and emerging infectious diseases. Nihon Rinsho. 2016;74:1956-61.

34. Vignier $\mathrm{N}$, Bouchaud $\mathrm{O}$. Travel, migration and emerging infectious diseases. EJIFCC. 2018;29:175-9.

35. Delisle E, Rousseau C, Broche B, Leparc-Goffart I, L'Ambert G, Cochet A, et al. Chikungunya outbreak in Montpellier, France, September to October 2014 Euro Surveill. 2015;20:21108.

36. Jacob E. Coronavirus: trois premiers cas confirmes en France, deux d'entre eux vont bien. 2020. https://www.lefigaro.fr/sciences/coronavirus-troispremiers-cas-confirmes-en-france-20200124. Accessed 26 Jul 2020.

37. Marchand E, Prat C, Jeannin C, Lafont E, Bergmann T, Flusin O, et al. Autochthonous case of dengue in France, October 2013. Euro Surveill. 2013; 18:20661.

38. van den Berg T. The role of the legal and illegal trade of live birds and avian products in the spread of avian influenza. Rev Sci Tech. 2009;28: 93-111.

39. World Health Organization. International health regulations (2005). 2016. https://www.who.int/ihr/publications/9789241580496/en/. Accessed 26 Jul 2020.

40. World Trade Organization. WTO agreements \& public health: a joint study by the WHO and the WTO Secretariat. 2002. https://www.wto.org/english/ res_e/booksp_e/who_wto_e.pdf. Accessed 26 Jul 2020.

41. Chinazzi M, Davis JT, Ajelli M, Gioannini C, Litvinova M, Merler S, et al. The effect of travel restrictions on the spread of the 2019 novel coronavirus (COVID-19) outbreak. Science. 2020;368:395-400.

42. Ferguson NM, Cummings DA, Fraser C, Cajka JC, Cooley PC, Burke DS. Strategies for mitigating an influenza pandemic. Nature. 2006;442:448-52.

43. Mateus AL, Otete HE, Beck CR, Dolan GP, Nguyen-Van-Tam JS. Effectiveness of travel restrictions in the rapid containment of human influenza: a systematic review. Bull World Health Organ. 2014;92:868-0D
44. Wood JG, Zamani N, Maclntyre CR. Effects of internal border control on spread of pandemic influenza. 2010. https://www.nc.cdc.gov/eid/article/13/ 7/06-0740_article. Accessed 26 Jul 2020.

45. Torner N. Risky trade: infectious disease in the era of global trade. J Epidemiol Community Health. 2007;61:926.

46. Hautier Y, Tilman D, Isbell F, Seabloom EW, Borer ET, Reich PB. Plant ecology. Anthropogenic environmental changes affect ecosystem stability via biodiversity. Science. 2015;348:336-40.

47. World Health Organization. Global environmental change. 2020. https:// www.who.int/globalchange/environment/en/. Accessed 26 Jul 2020.

48. National Academy of Sciences. Infectious disease emergence: microbial evolution and co-adaptation. England: National Academies Press; 2009.

49. Nava A, Shimabukuro JS, Chmura AA, Luz SLB. The impact of global environmental changes on infectious disease emergence with a focus on risks for Brazil. ILAR J. 2017:58:393-400.

50. Morens DM, Fauci AS. Emerging infectious diseases: threats to human health and global stability. PLoS Pathog. 2013;9:e1003467.

51. Morse SS. Factors and determinants of disease emergence. Rev Sci Tech. 2004;23:443-51.

52. Galvani AP, Bauch $C T$, Anand M, Singer BH, Levin SA. Human-environment interactions in population and ecosystem health. Proc Natl Acad Sci U S A. 2016;113:14502-6.

53. Semenza JC, Ebi KL. Climate change impact on migration, travel, travel destinations and the tourism industry. J Travel Med. 2019;26:taz026.

54. Wu X, Lu Y, Zhou S, Chen L, Xu B. Impact of climate change on human infectious diseases: empirical evidence and human adaptation. Environ Int. 2016:86:14-23.

55. UNHCR. Environment, disasters and climate change. 2020. http://www. unhcr.org/environment-disasters-and-climate-change.html. Accessed 26 Jul 2020.

56. Barbour AG, Fish D. The biological and social phenomenon of Lyme disease. Science. 1993:260:1610-6.

57. Cisse G, Alves MJ, Confalonieri U. Climate-sensitive infectious diseases. In: UNEP, editor. The adaptation gap report 2018. Nairobi: UNEP; 2018. p. 49-59.

58. Mclntyre KM, Setzkorn C, Hepworth PJ, Morand S, Morse AP, Baylis M Systematic assessment of the climate sensitivity of important human and domestic animals pathogens in Europe. Sci Rep. 2017;7:7134.

59. World Health Organization. Vector-borne diseases. Geneva: World Health Organization; 2020.

60. Caminade C, McIntyre KM, Jones AE. Impact of recent and future climate change on vector-borne diseases. Ann N Y Acad Sci. 2019;1436:157-73.

61. Choi SY, Kim JH, Kim J. World outbreak trend of infectious diseases with surveillance. J Bacteriol. 2019;49:141-51.

62. Ciota AT, Keyel AC. The role of temperature in transmission of zoonotic arboviruses. Viruses. 2019;11:1013.

63. Cissé G. Food-borne and water-borne diseases under climate change in low- and middle-income countries: further efforts needed for reducing environmental health exposure risks. Acta Trop. 2019:194:181-8.

64. Fenollar F, Mediannikov O. Emerging infectious diseases in Africa in the 21st century. New Microbes New Infect. 2018;26:S10-8.

65. Morse SS. Factors in the emergence of infectious diseases. Emerg Infect Dis. 1995;1:7-15.

66. Department of Economic Social Affairs Disability. Envision2030: 17 goals to transform the world for persons with disabilities. 2020. https://www.un.org/ development/desa/disabilities/envision2030.html. Accessed 26 Jul 2020.

67. Rockström J, Williams J, Daily G, Noble A, Matthews N, Gordon L, et al. Sustainable intensification of agriculture for human prosperity and global sustainability. Ambio. 2017:46:4-17.

68. Rohr JR, Barrett CB, Civitello DJ, Craft ME, Delius B, DeLeo GA, et al. Emerging human infectious diseases and the links to global food production. Nat Sustain. 2019;2:445-56.

69. Shah HA, Huxley P, Elmes J, Murray KA. Agricultural land-uses consistently exacerbate infectious disease risks in Southeast Asia. Nat Commun. 2019;10: 4299.

70. Mayer JD. Geography, ecology and emerging infectious diseases. Soc Sci Med. 2000:50:937-52.

71. Morse SS, Schluederberg A. From the national institute of allergy and infectious diseases, the fogarty international center of the national institutes of health, and the rockefeller university. Emerging viruses: the evolution of viruses and viral diseases. J Infect Dis. 1990;162:1-7. 
72. Wolfe ND, Daszak P, Kilpatrick AM, Burke DS. Bushmeat hunting, deforestation, and prediction of zoonotic disease. Emerg Infect Dis. 2005;11:6.

73. Domestic animals and infectious diseases of man. J Am Med Assoc. 1902; XXXVIII:1520-1.

74. World Health Organization. Animal-human interface for health. https:// www.who.int/myanmar/activities/animal\%2D\%2Dhuman-interface-forhealth. Accessed 26 Jul 2020.

75. Roche B, Guégan JF. Ecosystem dynamics, biological diversity and emerging infectious diseases. C R Biol. 2011;334:385-92.

76. Knobler S, Mahmoud A, Lemon S, Pray L. The impact of globalization on infectious disease emergence and control exploring the consequences and opportunities workshop summary. Washington, DC: National Academies Press; 2006.

77. Kurpiers LA, Schulte-Herbrüggen B, Ejotre I, Reeder DM. Bushmeat and emerging infectious diseases: lessons from africa. In: Angelici FM, editor. Problematic wildlife: a cross-disciplinary approach. Cham: Springer International Publishing; 2016. p. 507-51.

78. Morand S, McIntyre KM, Baylis M. Domesticated animals and human infectious diseases of zoonotic origins: domestication time matters. Infect Genet Evol. 2014:24:76-81.

79. Hoberg EP, Alkire NL, de Queiroz A, Jones A. Out of Africa: origins of the Taenia tapeworms in humans. Proc Biol Sci. 2001;268:781-7.

80. Childs JE, Gordon ER. Surveillance and control of zoonotic agents prior to disease detection in humans. Mt Sinai J Med. 2009;76:421-8.

81. Angeletti S, Ceccarelli G, Vita S, Dicuonzo G, Lopalco M, Dedej E, et al. Unusual microorganisms and antimicrobial resistances in a group of Syrian migrants: sentinel surveillance data from an asylum seekers centre in Italy. Travel Med Infect Dis. 2016;14:115-22

82. Kilonzo C, Stopka TJ, Chomel B. Illegal animal and (bush) meat trade associated risk of spread of viral infections. In: Singh SK, editor. Viral infections and global change chapter: 10 llegal animal and (bush) meat trade associated risk of spread of viral infection. Hoboken: Wiley; 2013. p 179-94

83. Institute of Medicine. Forum on emerging infections. In: Harrison PF, Lederberg J, editors. Antimicrobial resistance: issues and options. Washington, DC: The National Academies Press; 1998. p. 128.

84. Boucher HW, Talbot GH, Bradley JS, Edwards JE, Gilbert D, Rice LB, et al. Bad bugs, no drugs: no ESKAPE! an update from the infectious diseases society of America. Clin Infect Dis. 2009:48:1-12.

85. Spellberg B, Guidos R, Gilbert D, Bradley J, Boucher HW, Scheld WM, et al. The epidemic of antibiotic-resistant infections: a call to action for the medical community from the infectious diseases society of America. Clin Infect Dis. 2008:46:155-64.

86. Taubes G. The bacteria fight back. Science. 2008;321:356-61.

87. Review on Antimicrobial Resistance. Tackling drug-resistant infections globally: final report and recommendations. Review on Antimicrobial Resistance; 2016

88. United Nations Interagency Coordination Group on Antimicrobial Resistance. AMR framework for action supported by the IACG. Working document. Geneva: United Nations Interagency Coordination Group on Antimicrobial Resistance; 2017.

89. World Bank. Drug-resistant infections: a threat to our economic future (discussion draft). Washington, DC: World Bank; 2016.

90. Centers for Disease Control and Prevention (CDC). Notes from the field: New Delhi metallo-beta-lactamase-producing Escherichia coli associated with endoscopic retrograde cholangiopancreatography - Illinois, 2013. MMWR Morb Mortal Wkly Rep. 2014;62:1051.

91. Centers for Disease Control and Prevention (CDC). Notes from the field: hospital outbreak of carbapenem-resistant Klebsiella pneumoniae producing New Delhi metallo-beta-lactamase--Denver, Colorado, 2012. MMWR Morb Mortal Wkly Rep. 2013;62:108

92. Centers for Disease Control and Prevention (CDC). Carbapenem-resistant Klebsiella pneumoniae associated with a long-term care facility-West Virginia, 2009-2011. MMWR Morb Mortal Wkly Rep. 2011;60:1418-20.

93. Doi Y, Paterson DL. Carbapenemase-producing Enterobacteriaceae. Semin Respir Crit Care Med. 2015;36:74-84.

94. McGann P, Hang J, Clifford RJ, Yang Y, Kwak YI, Kuschner RA, et al. Complete sequence of a novel 178-kilobase plasmid carrying bla(NDM-1) in a Providencia stuartii strain isolated in Afghanistan. Antimicrob Agents Chemother. 2012;56:1673-9.
95. Ochman H, Moran NA. Genes lost and genes found: evolution of bacterial pathogenesis and symbiosis. Science. 2001;292:1096-9.

96. Usluer G, Ozgunes I, Leblebicioglu H. A multicenter point-prevalence study: antimicrobial prescription frequencies in hospitalized patients in Turkey. Ann Clin Microbiol Antimicrob. 2005;4:16.

97. Saleh N, Awada S, Awwad R, Jibai S, Arfoul C, Zaiter L, et al. Evaluation of antibiotic prescription in the Lebanese community: a pilot study. Infect Ecol Epidemiol. 2015:5:27094.

98. Neu HC. The crisis in antibiotic resistance. Science. 1992;257:1064-73.

99. Cohen ML. Changing patterns of infectious disease. Nature. 2000;406:762-7.

100. European Centre for Disease Prevention Control. Antimicrobial resistance surveillance in Europe 2015. Annual report of the European antimicrobial resistance surveillance network (EARS-Net). Stockholm: ECDC. p. 2015.

101. Nakou A, Woodhead M, Torres A. MRSA as a cause of community-acquired pneumonia. Eur Respir J. 2009:34:1013-4.

102. Vardakas KZ, Matthaiou DK, Falagas ME. Incidence, characteristics and outcomes of patients with severe community acquired-MRSA pneumonia. Eur Respir J. 2009;34:1148-58.

103. Livermore DM, Canton R, Gniadkowski M, Nordmann P, Rossolini GM, Arlet G, et al. CTX-M: changing the face of ESBLs in Europe. J Antimicrob Chemother. 2007:59:165-74.

104. Queenan AM, Bush K. Carbapenemases: the versatile beta-lactamases. Clin Microbiol Rev. 2007;20:440-58 table of contents.

105. Peleg AY, Seifert $H$, Paterson DL. Acinetobacter baumannii: emergence of a successful pathogen. Clin Microbiol Rev. 2008;21:538-82.

106. Basu A, Garg P, Datta S, Chakraborty S, Bhattacharya T, Khan A, et al. Vibrio cholerae 0139 in Calcutta, 1992-1998: incidence, antibiograms, and genotypes. Emerg Infect Dis. 2000;6:139-47.

107. Faruque SM, Abdul Alim AR, Rahman MM, Siddique AK, Sack RB, Albert MJ. Clonal relationships among classical Vibrio cholerae 01 strains isolated between 1961 and 1992 in Bangladesh. J Clin Microbiol. 1993;31:2513-6.

108. Mukhopadhyay AK, Garg S, Mitra R, Basu A, Rajendran K, Dutta D, et al. Temporal shifts in traits of Vibrio cholerae strains isolated from hospitalized patients in Calcutta: a 3-year (1993 to 1995) analysis. J Clin Microbiol. 1996; 34:2537-43

109. Sharma C, Maiti S, Mukhopadhyay AK, Basu A, Basu I, Nair GB, et al. Unique organization of the CTX genetic element in Vibrio cholerae 0139 strains which reemerged in Calcutta, India, in September 1996. J Clin Microbiol. 1997;35:3348-50.

110. European Centre for Disease PC. Tuberculosis surveillance and monitoring in Europe 2012. 2020. https://www.ecdc.europa.eu/en/publications-data/ tuberculosis-surveillance-and-monitoring-europe-2012. Accessed 26 Jul 2020.

111. Loddenkemper R, Sotgiu G, Mitnick CD. Cost of tuberculosis in the era of multidrug resistance: will it become unaffordable? Eur Respir J. 2012:40:9-11.

112. Vidaver AK. Uses of antimicrobials in plant agriculture. Clin Infect Dis. 2002; 34:S107-10.

113. Aarestrup F. Sustainable farming: get pigs off antibiotics. Nature. 2012;486: 465-6.

114. Addis Z, Kebede N, Worku Z, Gezahegn H, Yirsaw A, Kassa T. Prevalence and antimicrobial resistance of Salmonella isolated from lactating cows and in contact humans in dairy farms of Addis Ababa: a cross sectional study. BMC Infect Dis. 2011;11:222

115. Doyle ME. Multidrug-resistant pathogens in the food supply. Foodborne Pathog Dis. 2015;12:261-79.

116. Fortini D, Fashae K, Garcia-Fernandez A, Villa L, Carattoli A. Plasmidmediated quinolone resistance and beta-lactamases in Escherichia coli from healthy animals from Nigeria. J Antimicrob Chemother. 2011;66:1269-72.

117. Kikuvi GM, Ombui JN, Mitema ES. Serotypes and antimicrobial resistance profiles of Salmonella isolates from pigs at slaughter in Kenya. J Infect Dev Ctries. 2010;4:243-8.

118. Mezali L, Hamdi TM. Prevalence and antimicrobial resistance of Salmonella isolated from meat and meat products in Algiers (Algeria). Foodborne Pathog Dis. 2012;9:522-9.

119. Mitema ES, Kikuvi GM, Wegener HC, Stohr K. An assessment of antimicrobial consumption in food producing animals in Kenya. J Vet Pharmacol Ther. 2001;24:385-90.

120. Simango C, Rukure G. Potential sources of Campylobacter species in the homes of farmworkers in Zimbabwe. J Trop Med Hyg. 1991;94:388-92.

121. Wall B, Mateus A, Marshall L, Pfeiffer D, Lubroth J, Ormel H, et al. Drivers, dynamics and epidemiology of antimicrobial resistance in animal production. Rome: Food and Agriculture Organization; 2016. 
122. Witte W. Medical consequences of antibiotic use in agriculture. Science. 1998;279:996-7.

123. Byarugaba DK. A view on antimicrobial resistance in developing countries and responsible risk factors. Int J Antimicrob Agents. 2004;24:105-10.

124. Laxminarayan R, Duse A, Wattal C, Zaidi AK, Wertheim HF, Sumpradit N, et al. Antibiotic resistance-the need for global solutions. Lancet Infect Dis. 2013;13:1057-98.

125. Okeke IN, Klugman KP, Bhutta ZA, Duse AG, Jenkins P, O'Brien TF, et al. Antimicrobial resistance in developing countries. Part II: strategies for containment. Lancet Infect Dis. 2005;5:568-80.

126. World Health Organization. Assessing non-prescription and inappropriate use of antibiotics: report on survey. 2019. https://apps.who.int/iris/bitstream/ handle/10665/312306/9789289054089-eng.pdf? sequence=1\&isAllowed=y. Accessed 26 Jul 2020.

127. Alliance for the Prudent Use of Antibiotics. Executive summary: select findings, conclusions, and policy recommendations. Clin Infect Dis. 2005;41: S224-7.

128. Goossens H, Ferech M, Vander Stichele R, Elseviers M. Outpatient antibiotic use in Europe and association with resistance: a cross-national database study. Lancet. 2005;365:579-87.

129. Kunin CM. Resistance to antimicrobial drugs - a world wide calamity. Ann Intern Med. 1993;118:557-61.

130. Okeke IN, Lamikanra A, Edelman R. Socioeconomic and behavioral factors leading to acquired bacterial resistance to antibiotics in developing countries. Emerg Infect Dis. 1999;5:18-27.

131. Okeke IN, Laxminarayan R, Bhutta ZA, Duse AG, Jenkins P, O'Brien TF, et al. Antimicrobial resistance in developing countries. Part $\mathrm{I}$ : recent trends and current status. Lancet Infect Dis. 2005:5:481-93.

132. Fridkin S, Baggs J, Fagan R, Magill S, Pollack LA, Malpiedi P, et al. Vital signs: improving antibiotic use among hospitalized patients. MMWR Morb Mortal Wkly Rep. 2014;63:194-200.

133. Marston HD, Dixon DM, Knisely JM, Palmore TN, Fauci AS. Antimicrobial resistance. JAMA. 2016;316:1193-204.

134. Hill AV. The immunogenetics of human infectious diseases. Annu Rev Immunol. 1998;16:593-617.

135. Lederberg JJBS. Haldane (1949) on infectious disease and evolution. Genetics. 1999;153:1-3.

136. Weatherall DJ. The genetics of common diseases: the implications of population variability. CIBA Found Symp. 1996;197:300-8 discussion 8-11.

137. Weatherall DJ. Host genetics and infectious disease. Parasitology. 1996;112: S23-9.

138. Rice AL, Sacco L, Hyder A, Black RE. Malnutrition as an underlying cause of childhood deaths associated with infectious diseases in developing countries. Bull World Health Organ. 2000:78:1207-21.

139. World Health Organization. Fifty-third world health assembly, provisional agenda item 12.4, A53/7. Infant and young child nutrition, Report by the director-general. 2000. https://apps.who.int/gb/archive/pdf_files/WHA53/ea7. pdf. Accessed 26 Jul 2020.

140. Dixon DM, McNeil MM, Cohen ML, Gellin BG, La Montagne JR. Fungal infections: a growing threat. Public Health Rep. 1996;111:226-35.

141. Morris JG Jr, Potter M. Emergence of new pathogens as a function of changes in host susceptibility. Emerg Infect Dis. 1997;3:435-41.

142. Yan QL, Tang SY, Xiao YN. Impact of individual behaviour change on the spread of emerging infectious diseases. Stat Med. 2018;37:948-69.

143. Rockville. Improving cultural competence. 2020. https://store.samhsa.gov/ sites/default/files/d7/priv/sma14-4849.pdf. Accessed 26 Jul 2020.

144. Mawar N, Saha S, Pandit A, Mahajan U. The third phase of HIV pandemic: social consequences of HIV/AIDS stigma \& discrimination \& future needs. Indian J Med Res. 2005;122:471-84

145. Vinck P, Pham PN, Bindu KK, Bedford J, Nilles EJ. Institutional trust and misinformation in the response to the 2018-19 Ebola outbreak in North Kivu, DR Congo: a population-based survey. Lancet Infect Dis. 2019;19:52936.

146. Yin W, Couzin O. HIV-related stigma and discrimination in China. In: Wu Z, Wang Y, Detels R, Bulterys M, McGoogan JM, editors. HIV/AIDS in China: epidemiology, prevention and treatment. Singapore: Springer; 2020. p. 51541.

147. Agnieszka R, Jan OA. Conflicts of human behavior in organizations and the influence of human factor on innovation. IOSR J Bus Manag. 2016;18:35-41.

148. Bloom DE, Cadarette D. Infectious disease threats in the twenty-first century: strengthening the global response. Front Immunol. 2019;10:549.
149. Gayer M, Legros D, Formenty P, Connolly MA. Conflict and emerging infectious diseases. Emerg Infect Dis. 2007;13:1625-31.

150. Sharara SL, Kanj SS. War and infectious diseases: challenges of the Syrian civil war. PLoS Pathog. 2014;10:e1004438.

151. Abbas M, Aloudat T, Bartolomei J, Carballo M, Durieux-Paillard S, Gabus L, et al. Migrant and refugee populations: a public health and policy perspective on a continuing global crisis. Antimicrob Resist Infect Control. 2018;7:113.

152. Heywood AE, Castelli F, Greenaway C. Migration health: highlights from inaugural international society of travel medicine (ISTM) conference on migration health. Curr Infect Dis Rep. 2019;21:48.

153. Seedat F, Hargreaves S, Nellums LB, Ouyang J, Brown M, Friedland JS. How effective are approaches to migrant screening for infectious diseases in Europe? A systematic review. Lancet Infect Dis. 2018;18:NIMe259-71.

154. UNHCR. Figures at a glance. 2020. http://www.unhcr.org/figures-at-a-glance. html. Accessed 26 Jul 2020.

155. Nimer NA. A review on emerging and reemerging of infectious diseases in Jordan: the aftermath of the Syrian crises. Can J Infect Dis Med Microbiol. 2018;2018:8679174.

156. Ozaras R, Leblebicioglu H, Sunbul M, Tabak F, Balkan II, Yemisen M, et al. The Syrian conflict and infectious diseases. Expert Rev Anti-Infect Ther. 2016; 14:547-55.

157. Centers for Disease Control Prevention. Coronavirus disease 2019 (COVID2019). 2020. https://www.cdc.gov/coronavirus/2019-ncov/cdcresponse/ about-COVID-19.html. Accessed 1 Sep 2020.

158. World Health Organization. Naming the coronavirus disease (COVID-19) and the virus that causes it. 2020. https://www.who.int/emergencies/diseases/ novel-coronavirus-2019/technical-guidance/naming-the-coronavirus-disease(covid-2019)-and-the-virus-that-causes-it. Accessed 17 Aug 2020.

159. Gorbalenya AE, Baker SC, Baric RS, de Groot RJ, Drosten C, Gulyaeva AA, et al. Severe acute respiratory syndrome-related coronavirus: the species and its viruses_-a statement of the Coronavirus Study Group. bioRxiv. 2020 https://doi.org/10.1101/2020.02.07.937862.

160. Lu H, Stratton CW, Tang YW. Outbreak of pneumonia of unknown etiology in Wuhan, China: the mystery and the miracle. J Med Virol. 2020;92:401-2.

161. World Health Organization. WHO director-general's remarks at the media briefing on 2019-nCoV on 11 February 2020. 2020. https://www.who.int/dg/ speeches/detail/who-director-general-s-remarks-at-the-media-briefing-on-2 019-ncov-on-11-february-2020. Accessed 26 Jul 2020.

162. Novel Coronavirus Pneumonia Emergency Response Epidemiology Team. The epidemiological characteristics of an outbreak of 2019 novel coronavirus diseases (COVID-19)_China, 2020. China CDC Wkly. 2020;2:113-

163. World Health Organization. WHO Coronavirus disease (COVID-19) dashboard. 2020. https://covid19.who.int/. Accessed 26 Jul 2020.

164. World Health Organization. Home care for patients with COVID-19 presenting with mild symptoms and management of their contacts. 2020. https://www.who.int/publications/i/item/home-care-for-patients-withsuspected-novel-coronavirus-(ncov)-infection-presenting-with-mildsymptoms-and-management-of-contacts. Accessed 26 Jul 2020

165. Hui DS, Azhar El, Kim YJ, Memish ZA, Oh MD, Zumla A. Middle East respiratory syndrome coronavirus: risk factors and determinants of primary, household, and nosocomial transmission. Lancet Infect Dis. 2018;18:e21727.

166. Peiris JSM, Guan Y, Yuen KY. Severe acute respiratory syndrome. Nat Med. 2004;10:S88-97.

167. Riou J, Althaus CL. Pattern of early human-to-human transmission of Wuhan 2019 novel coronavirus (2019-nCoV), December 2019 to January 2020. Euro Surveill. 2020;25:2000058

168. Wang Y, Wu W, Cheng Z, Tan X, Yang Z, Zeng X, et al. Super-factors associated with transmission of occupational COVID-19 infection among healthcare staff in Wuhan, China. J Hosp Infect. 2020;106:25-34.

169. Li X, Zai J, Zhao Q, Nie Q, Li Y, Foley BT, et al. Evolutionary history, potential intermediate animal host, and cross-species analyses of SARS-CoV-2. J Med Virol. 2020;92:602-11.

170. Liu $P$, Jiang J-Z, Wan X-F, Hua Y, Wang X, Hou F, et al. Are pangolins the intermediate host of the 2019 novel coronavirus (2019-nCoV)? bioRxiv. 2020 https://doi.org/10.1101/2020.02.18.954628.

171. Lu R, Zhao X, Li J, Niu P, Yang B, Wu H, et al. Genomic characterisation and epidemiology of 2019 novel coronavirus: implications for virus origins and receptor binding. Lancet. 2020;395:565-74. 
172. Zhou $P$, Yang $X L$, Wang $X G$, Hu B, Zhang L, Zhang W, et al. A pneumonia outbreak associated with a new coronavirus of probable bat origin. Nature. 2020;579:270-3.

173. U. S. Food and Drug Administration. FDA warns consumers about the dangerous and potentially life-threatening side effects of miracle mineral solution. 2020. Accessed 10 Mar 2020.

174. The New York Times. Surge of virus misinformation stumps Facebook and Twitter. 2020. Accessed 10 Mar 2020.

175. BBC News Singapore. Coronavirus: why some countries wear face masks and others don't. 2020. https://www.bbc.com/news/world-52015486. Accessed 26 Jul 2020.

176. Mian A, Khan S. Coronavirus: the spread of misinformation. BMC Med. 2020; 18:89.

177. Ren SY, Gao RD, Chen YL. Fear can be more harmful than the severe acute respiratory syndrome coronavirus 2 in controlling the corona virus disease 2019 epidemic. World J Clin Cases. 2020;8:652-7.

178. Grace H. Japan may have beaten coronavirus without lockdowns or mass testing. But how? 2020. https://time.com/5842139/japan-beat-coronavirustesting-lockdowns/. Accessed 26 Jul 2020.

179. Hasan Muhammad B, Mizanur R, Mohammad Tareq H. The COVID-19 pandemic: why are some countries more successful than others? 2020. https://papers.ssrn.com/sol3/papers.cfm?abstract_id=3575251. Accessed 26 Jul 2020.

180. Alex W. How Spain's coronavirus outbreak got so bad so fast-and how Spaniards are trying to cope. 2020. https://www.vox.com/2020/3/20/211 83315/coronavirus-spain-outbreak-cases-tests. Accessed 27 Jul 2020.

181. Sara B. 5 reasons the coronavirus hit Italy so hard. 2020. https:// theconversation.com/5-reasons-the-coronavirus-hit-italy-so-hard-134636. Accessed 27 Jul 2020.

182. Raghupathi V. An empirical investigation of chronic diseases: a visualization approach to medicare in the United States. Int J Healthc Manag. 2019;12: 327-39.

183. Young BE, Ong SWX, Kalimuddin S, Low JG, Tan SY, Loh J, et al. Epidemiologic features and clinical course of patients infected with SARSCoV-2 in Singapore. JAMA. 2020;323:1488-94.

184. Zhou F, Yu T, Du R, Fan G, Liu Y, Liu Z, et al. Clinical course and risk factors for mortality of adult inpatients with COVID-19 in Wuhan, China: a retrospective cohort study. Lancet. 2020;395:1054-62.

185. Lowen AC, Mubareka S, Steel J, Palese P. Influenza virus transmission is dependent on relative humidity and temperature. PLoS Pathog. 2007;3: 1470-6.

186. Harvard Health Publishing. Out in the cold. 2010. https://www.health. harvard.edu/staying-healthy/out-in-the-cold. Accessed 27 Jul 2020

187. Woodward A. High temperatures and muggy weather might make the new coronavirus less contagious, a group of experts says. 2020. https://www. businessinsider.in/science/news/high-temperatures-and-muggy-weathermight-make-the-new-coronavirus-less-contagious-a-group-of-experts-says/ articleshow/74697538.cms. Accessed 27 Jul 2020

188. Bannister-Tyrrell M, Meyer A, Faverjon C, Cameron A. Preliminary evidence that higher temperatures are associated with lower incidence of COVID-19, for cases reported globally up to 29th February 2020. medRxiv. 2020. https://doi.org/10.1101/2020.03.18.20036731.

189. Chan KH, Peiris JS, Lam SY, Poon LL, Yuen KY, Seto WH. The effects of temperature and relative humidity on the viability of the SARS coronavirus. Adv Virol. 2011;2011:734690.

190. Boldog P, Tekeli T, Vizi Z, Dénes A, Bartha FA, Röst G. Risk assessment of novel coronavirus COVID-19 outbreaks outside China. J Clin Med. 2020;9: 571.

191. Booth TF, Kournikakis B, Bastien N, Ho J, Kobasa D, Stadnyk L, et al. Detection of airborne severe acute respiratory syndrome (SARS) coronavirus and environmental contamination in SARS outbreak units. J Infect Dis. 2005; 191:1472-7.

192. Donnelly CA, Ghani AC, Leung GM, Hedley AJ, Fraser C, Riley S, et al. Epidemiological determinants of spread of causal agent of severe acute respiratory syndrome in Hong Kong. Lancet. 2003;361:1761-6.

193. Ijaz MK, Brunner AH, Sattar SA, Nair RC, Johnson-Lussenburg CM. Survival characteristics of airborne human coronavirus 229E. J Gen Virol. 1985;66: 2743-8

194. Mangen MJ, Nielen M, Burrell AM. Simulated effect of pig-population density on epidemic size and choice of control strategy for classical swine fever epidemics in The Netherlands. Prev Vet Med. 2002;56:141-63.
195. Camilo R. As the number of elderly people with coronavirus varies between countries. 2020. https://www.nexojornal.com.br/expresso/2020/03/18/Comoo-número-de-idosos-comcoronavírus-varia-entre-países. Accessed $27 \mathrm{Jul}$ 2020.

196. Mas-Coma S, Jones MK, Marty AM. COVID-19 and globalization. One Health. 2020;9:100132.

197. Zhai Y, Du X. Mental health care for international Chinese students affected by the COVID-19 outbreak. Lancet Psychiatry. 2020;7:e22.

198. St John RK, King A, de Jong D, Bodie-Collins M, Squires SG, Tam TW. Border screening for SARS. Emerg Infect Dis. 2005;11:6-10.

199. Jason B. How South Korea reined in the outbreak without shutting everything down. 2020. https://www.npr.org/sections/goatsandsoda/2020/ 03/26/821688981/how-south-korea-reigned-in-the-outbreak-withoutshutting-everything-down. Accessed 27 Jul 2020.

200. Shibani M, Simon D. How the U.S. can defeat coronavirus: Heed Asia's lessons from past epidemics. 2020. https://www.washingtonpost.com/ world/asia_pacific/how-the-us-can-defeat-coronavirus-heed-asias-lessonsfrom-epidemics-past/2020/03/18/9aa7916a-67a5-11ea-b199-3a9799c54512_ story.html. Accessed $27 \mathrm{Jul} 2020$.

201. Artika IM, Ma'roef CN. Laboratory biosafety for handling emerging viruses. Asian Pac J Trop Biomed. 2017;7:483-91.

202. Peng H, Bilal M, labal HMN. Improved biosafety and biosecurity measures and/or strategies to tackle laboratory-acquired infections and related risks. Int J Environ Res Public Health. 2018;15:2697.

\section{Publisher's Note}

Springer Nature remains neutral with regard to jurisdictional claims in published maps and institutional affiliations.
Ready to submit your research? Choose BMC and benefit from:

- fast, convenient online submission

- thorough peer review by experienced researchers in your field

- rapid publication on acceptance

- support for research data, including large and complex data types

- gold Open Access which fosters wider collaboration and increased citations

- maximum visibility for your research: over $100 \mathrm{M}$ website views per year

At $\mathrm{BMC}$, research is always in progress.

Learn more biomedcentral.com/submissions 